\title{
A GYÁRTÁS DIGITALIZÁLÁSA - KIHÍVÁS AZ IPAR ÉS AZ OKTATÁS RÉSZÉRE
}

\section{DIGITALIZATION OF PRODUCTION - A CHALLENGE FOR THE INDUSTRY AND EDUCATION}

\author{
Forgó Zoltán, ${ }^{1}$ Tolvaly-Roşca Ferenc, ${ }^{2}$ Farmos Rudolf ${ }^{3}$ \\ Sapientia EMTE, Marosvásárhelyi Kar, Gépészmérnöki Tanszék, Marosvásárhely, Románia \\ ${ }^{1}$ zforgo@ms.sapientia.ro \\ 2 tferi@ms.sapientia.ro \\ ${ }^{3}$ farmos_rudolf@ms.sapientia.ro
}

\begin{abstract}
Today's industry relies not only on raw material processing, but also on information. The huge amount of data obtained during the production process of goods and services; as well as information about the context of the production processes has made it necessary to account for, methodize, analyze and react in order to achieve a competitive market share. Fortunately, this technological leap has been able to support the above process, but the presence of those new technologies requires adequate preparation from the point of view of human resources too.
\end{abstract}

Keywords: digitalization, Industry 4.0, information technology, education.

\section{Összefoglalás}

Napjaink termékeinek a megvalósítása nem csak a nyersanyag-feldolgozásra támaszkodik, hanem fontos szerepet játszik az információfeldolgozás is. A termékek vagy szolgáltatások előállításakor óriási mennyiségű adat lát napvilágot, illetve a gyártási környezet változásáról begyüjtött információk is mind szükségessé tették ezen adatok figyelembevételét, rendszerezését, vizsgálatát, és egy versenyképes piaci jelenlét érdekében elengedhetetlenek az ezek alapján tervezett válaszakciók. A fenti folyamatot lehetővé teszi az aktuális technológiai fejlődés, viszont ugyanennyire fontos a technológiák felügyeletében, felhasználásában részt vevő személyzet megfelelő felkészítése is.

Kulcsszavak: digitalizáció, Ipar 4.0, információ-technológia, oktatás.

\section{A negyedik ipari forradalom}

Amikor a számítógépeket a 20. század második felében bevezették az iparba, egy egészen új dimenziója valósult meg a gyártásnak. Ezek a hardvereszközök alapjában véve nem sokat változtak, viszont azzal, hogy hálózatba szervezték ezeket és kommunikálni tudnak egymással, illetve döntéseket hozni emberi beavatkozás nélkül, egy újabb szintre emelték a gyártási folyamatok vezérlését. A kiberfizikai rendszerek, a dolgok internete (IoT - Internet of things) lehetővé tette, hogy a negye- dik ipari forradalomról beszéljünk (1. ábra). Így az Ipar 4.0 keretén belül megvalósulhat a Smart Factory (intelligens gyár): a hálózatba kötött gyártóberendezések egyre több adathoz férnek hozzá, így a megfelelő algoritmusok segítségével nagyobb hatásfokú, nagyobb termelékenységű berendezésekké alakulnak, és mindez úgy történhet meg, hogy kevesebb hulladékot termelnek. Végül is az Ipar 4.0 erőssége abban áll, hogy lehetőségünk van ipari környezetben még több adatot generálni, gyüjteni és feldolgozni. 


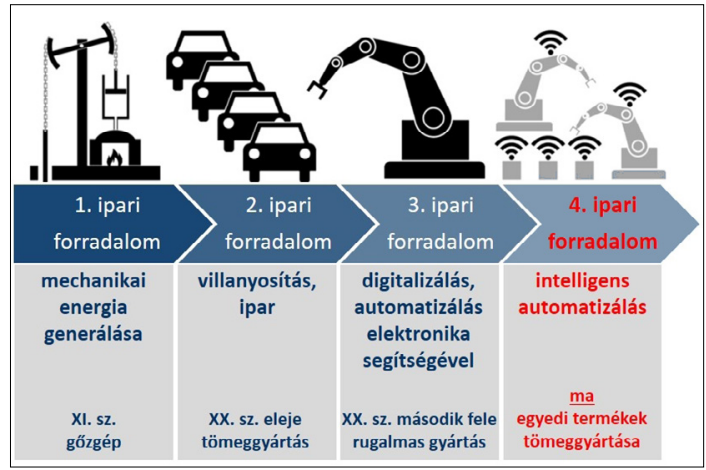

1. ábra. A 4. ipari forradalom elhelyezkedése az ipar fejlődésében

A fenti kijelentésből egyértelmű, hogy a Big Data (nagy adatmennyiség) fogalom egy alappillére a mai iparnak, és ez folytonos adatforrást szolgáltat a kiértékeléshez. Adatáramlatról beszélhetünk rendszerek, érzékelők és mobileszközök felől, melyek a gyártóegységben és/vagy azon kívül helyezkednek el, illetve adatgyűjtés zajlik hagyományos és digitális forrásokból egyaránt. Ez a nagy adatmennyiség képezi a mai szakemberek egyik nagy kihívását, mivel új adatértelmezési módszerek kidolgozását teszi szükségessé, amelyek a releváns adatokat választják ki, és ezek alapján hozzák meg döntéseiket.

A kiértékelt adatokat alkalmazni is szükséges. A Smart Factory az az entitás, mely automata módon teszi ezt meg, ezen belül a berendezések automata módon optimalizálják a folyamatokat, melyek tökéletes módon kapcsolódnak egymáshoz. Ez természetesen nemcsak a fizikai érintkezést jelenti, hanem a további adatcserét is, mely veszteség és torzulás nélkül használandó fel a gyártóegység bármelyik pontjában. Ebben nemcsak a belső adatok segítségével növeli termelékenységét, hanem az alkalmazkodási folyamat eredményeképpen visszahat a környezeti változásokra is.

A számítástechnika fejlődése lehetővé tette a számítási kapacitás növekedését, melynek egyik hozadéka a számítógépes grafika széles körű elterjedése lett. Ezt sikerült kombinálni a nagy mennyiségű adatfeldolgozással, és olyan eszközök láttak napvilágot, amelyek lehetővé tették a termékek, gyártóberendezések, sőt a gyártóegységek élethű modellezését. Ezek segítségével megszülettek azok a virtuális modellek, amelyek vizsgálata, kiértékelése lehetővé tette a termékek/szolgáltatások vizsgálatát, még mielőtt ezek megvalósításra, gyártásra kerültek volna. Ez költségcsökkenéssel járt a termékek esetében, illetve jelentősen lerövidítette a piacra vezetési időt (time-to-market). Az említett modellek a gyártórendszerek virtuális üzembe helyezését tették lehetővé, így korai fázisban sikerül elkerülni számos hibát, melyek a különböző berendezések összehangolásakor jelentkezhetnek, illetve lehetőséget adtak a vezérlések korai fejlesztésére, még mielőtt a berendezéseknek a hardver része fizikailag elkészülne. Olyan számítástechnikai eszközökről beszélhetünk napjainkban, melyek a kiberfizikai modellek (cyber-phisical models) [1] alkalmazását teszik tehát lehetővé, és melyekben a számítástechnikai eszközök, a hálózatok és a valós gyártórendszerek integrációja valósul meg. Ezen rendszerek automatizálása tulajdonképpen oda vezetett, hogy visszacsatolás révén számítógépek felügyelik, vezérlik és optimalizálják a valós folyamatokat, rendszereket. Ilyen például az ABB RobotStudio szoftvercsomag [2], mely keretén belül lehetőség van virtuálisan felépíteni egy robotizált cellát, illetve lehetőséget ad a cellában szereplő berendezések programozására és ezek együttműködése általi összehangolására. Ebben az esetben ugyanaz a vezérlőszoftver van beépítve a modellező eszközbe, mint amelyik a valós robotokat vezérli, így a cella megépítésekor gond nélkül át lehet vinni a vezérlőprogramot a virtuális világból a valós gyártósorra.

Mindezek mellett a mai fejlesztések azon irányba mutatnak, hogy a számítógépes hardver és szoftver beépítése a berendezésekbe elsősorban nem a számítási/vezérlési feladatra irányulnak, hanem alkalmazkodási és tanulási célokat is szolgálnak.

A fentiek alapján fontos az információ feldolgozása. De ennek előfeltétele, hogy az információ elérhető legyen időbeli és térbeli korlátok nélkül. Ehhez segít a dolgok internete (Internet of Things - IoT), mely gyüjtőfogalom a berendezések, mobil eszközök egymással és az internettel való öszszekötésére. Így, a felhő alapú szolgáltatásokon keresztül, elviekben korlátok nélkül, különböző érzékelőktől, adatbázisokból szolgáltatott adatok jelentik a berendezéseknek a bemenő információkat, melyek alapján automata módon, előre vagy valós időben tervezhetik működésüket. Mivel ezek a berendezések azonnali módon információt cserélhetnek, akár segíthetik is egymás működését, a dolgok internete mobil, azonnali csatlakozással rendelkező decentralizált számítástechnikai rendszernek tekinthető.

A felsorolt négy technológia (Big Data, Smart Factory, Cyber-Phisical Systems, Internet of Things) már a 2000-es évek elején is létezett külön-külön. 
Most érkezett el az idő, hogy az Ipar 4.0 korszak négy tartóoszlopa együttesen tudjon érvényesülni: a számítástechnikai eljárások lehetővé teszik a hibamentes adatáramlást az emberek, a kiberfizikai rendszerek és az intelligens gyártás között, ezeknek a dolgok internete segítségével történő összekötése esetében (2. ábra).

Az algoritmusok alkalmazása nagy változáson ment keresztül az utolsó évtizedben: a hagyományos IT-rendszerekről átkerült a mobil eszközökre és/vagy felhőszolgáltatássá alakult, és piacérett termékekként a behálózott új iparban alkalmazható.

Az Ipar 4.0 vázlatos képét tárja elénk a Clearpath Robotics cég, a németországi OTTO motors leányvállalata, melyben egyértelműen látható a valós és a virtuális üzem tükrözése, az információáramlás az üzemen kívülről (3. ábra). Ugyanitt vannak feltüntetve azon technológiák, melyek visszacsatolás révén a gyártást és a termékek minőségét is kedvezően befolyásolják: a kommunikálni tudó berendezések (Social Machines), az okostermékek (élettartamuk alatt információ-visszacsatolásra

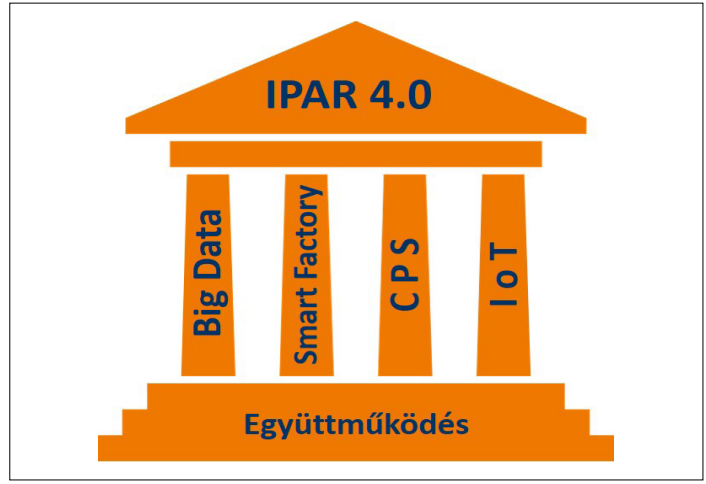

2. ábra. Az Ipar 4.0 nem más, mint négy technológiának (Big Data, Smart Factory, Cyber-Phisical System, Internet of Things) a szoros és összefonódó együttmüködése

képesek, így hatva a tervezésre, kivitelezésre), a kiterjesztett valóságot használó operátorok (Augmented Realty - pl. egy szemüveg segítségével lehetőséget ad plusz információt megjeleníteni valós berendezésekhez kötve), a virtuális gyártás térbeli korlátok nélküli környezetben.

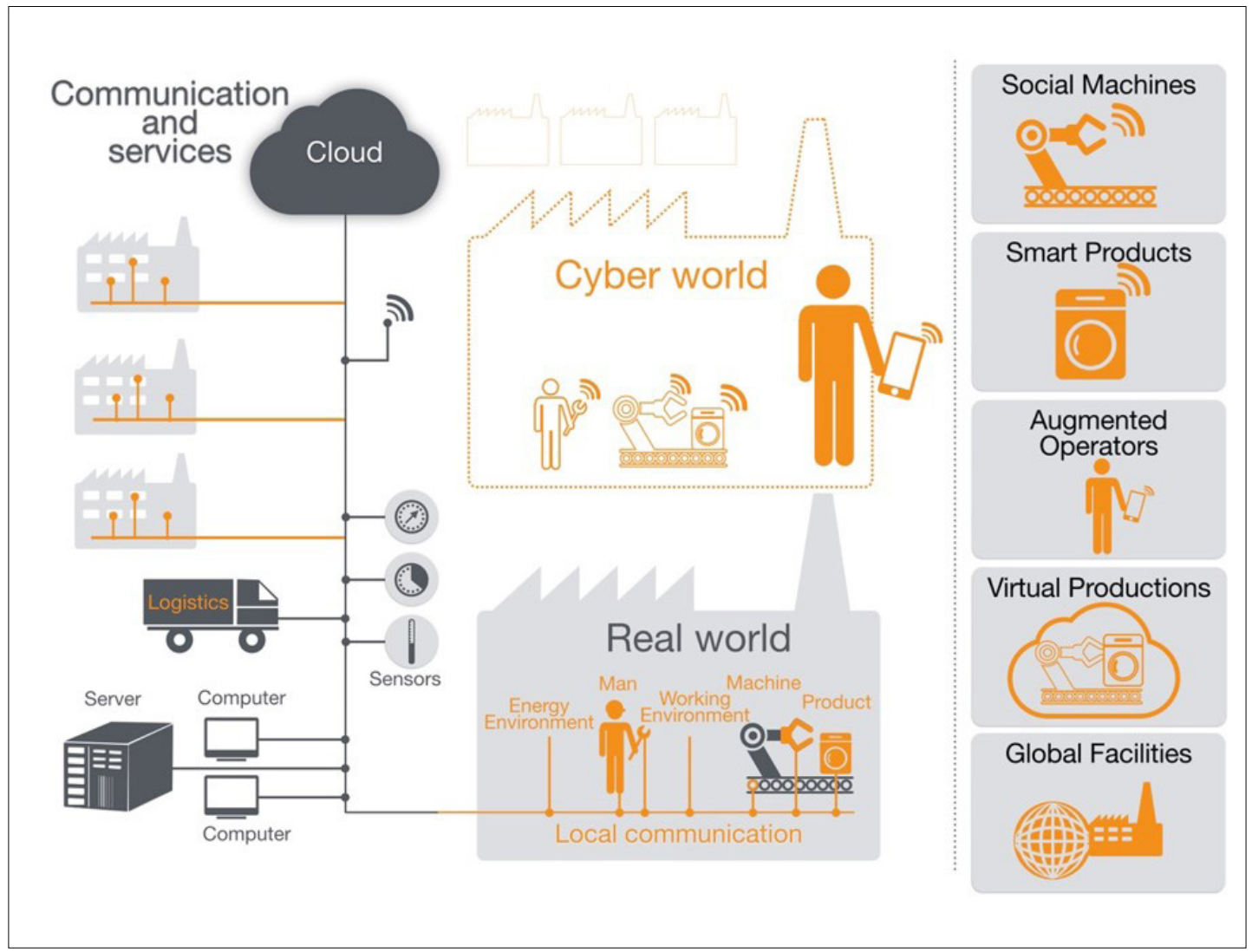




\section{Kihívás az oktatás számára}

Nagyon sok esetben a felsorolt technológiák és üzemi, ipari szintű megközelítések egyértelműen az Ipar 4.0 célját segítik és valósítják meg: egyedi termékeket tömeggyártó sorokon. Ennek megvalósítására egy gazdasági egységnek nemcsak a technológia szintjén kell felkészülnie, hanem a megfelelő humánerőforrással is kell rendelkeznie, hogy ezeket megfelelőképpen felügyelje és kiszolgálja.

A fentiek értelmében nehéz (de szükségszerűen rövid) út áll Románia előtt, mivel az Európai Bizottság 2019-es Human Capital Digital Inclusion and Skills (2017-es adatok) jelentése szerint Románia az utolsó helyen helyezkedik el a munkavállalók digitális kompetenciáinak kimutatásakor (6. old)-26\% nem rendelkezik egyáltalán digitális kompetenciával [4]. Ezek a kompetenciák pedig elengedhetetlenek az Ipar 4.0 céljainak megvalósításához.

A digitális kompetencia szintjét csakis az oktatással lehet növelni a munkavállalók körében, melyet az állam a formális oktatás (pl. számítástechnikai eszközhasználat) iskolába való bevezetésével vagy az állami hivatalok digitalizálásával érhet el. Ez utóbbi esetben a lakosság nagy része rákényszerül arra, hogy eredményes ügyintézés érdekében közelebb kerüljön a számítástechnikai eszközökhöz. Mindemellett a magánszektor is hozzájárulhat a digitális kompetencia oktatásához: ebben az esetben viszont már nem annyira széles körű oktatásról beszélhetünk, illetve profitorientált kezdeményezésről lévén szó, a különböző iparágak tovább szükíthetik az oktatott digitális kompetenciákat.

Habár 2015. április 7-én a 245. kormányrendelettel létrejön a Nemzeti Stratégia a Digitális Romániáért 2020 (Strategia Naţională privind Agenda Digitală pentru România 2020) [5], és létrehozzák a központi irodát (Agenția pentru Agenda Digitală a României), mely felügyeli a stratégia megvalósítását, a román ipar nem érzi ennek hatását, mivel a stratégiának nincs közvetlen módon rá fókuszáló pontja.

A stratégiában az iskolai oktatás és a felnőttoktatás terén kiemelt helyet kap a digitális kompe- tenciák általános fejlesztése (pl. az internethasználat), viszont a dokumentum a mai, digitális korszakban a munkavállalók számára elengedhetetlenül szükséges többi digitális ismeretre nem fókuszál.

Ezen akciók szükségességét nemcsak a kormányok szorgalmazzák, hanem a gazdasági szféra is felhívja a figyelmet az elkerülhetetlenre. Például Joe Kaeser, a SIEMENS AG elnöke és CEO-ja, folyó év júliusában a cég honlapján megjelenő Öt tevékenység egy erősebb Európáért dokumentumban [6] kifejti, hogy 2024-re a munkavállalók 50\%ának haladó digitális ismeretekkel kell rendelkezniük ahhoz, hogy Európának versenyképes ipara legyen. Ha Európának ez a szükséglete, akkor ez többszörösen is érvényes a közép-kelet-európai régióra.

Ezek értelmében a szakoktatás és az egyetemi oktatás kiemelt szerepet vállalhat és kell vállaljon a felnőttképzésben és a „lifelong learning” képzések és átképzések terén, hogy megtörténjen a felzárkóztatás a digitális kompetenciák terén.

\section{Szakirodalmi hivatkozások}

[1] VisualComponents szoftvercsomag https://www.visualcomponents.com/ (letöltve: 2020. február 26.)

[2] ABB RobotStudio szoftvercsomag https://new.abb.com/products/robotics/robotstudio (letöltve: 2020. február 26.)

[3] OTTO motors Blog https://ottomotors.com/blog/understanding-industry-4-0 (letöltve: 2020. február 26.)

[4] Európai Bizottság: Human Capital Digital Inclusion and Skills. 2019.

https://ec.europa.eu/newsroom/dae/document. cfm?doc_id=59976 (letöltve: 2020. február 26.)

[5] Nemzeti Stratégia a Digitális Romániáért 2020 https://www.comunicatii.gov.ro/wp-content/ uploads/2016/02/Strategia-Nationala-AgendaDigitala-pentru-Romania-2020-aprobata-feb-2015.doc (letöltve: 2020. február 26.)

[6] SIEMENS AG: Öt tevékenység egy erösebb Európáért

https://assets.new.siemens.com/siemens/ assets/api/uuid:af869324-cddb-4b73-a63bf37871293cb7/Siemens-EU-Industrial-Policy-EN. pdf (letöltve: 2020. február 26.) 